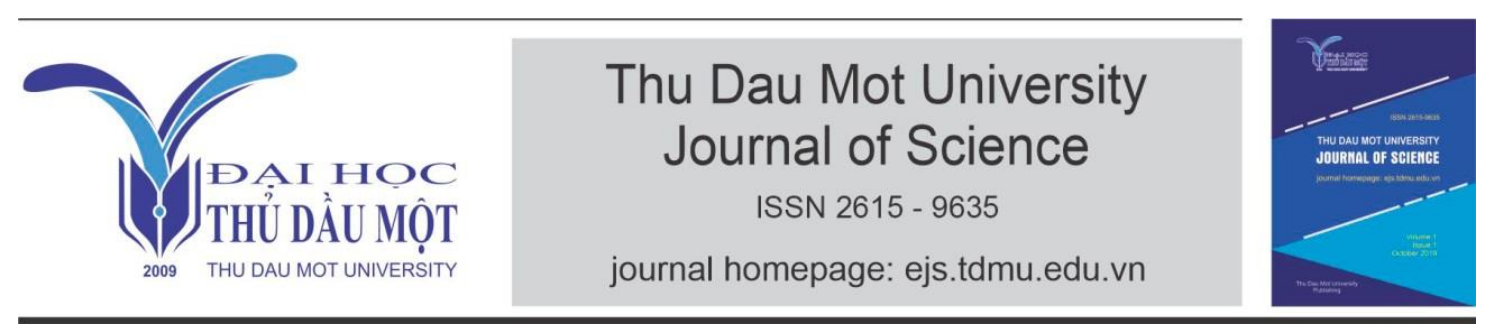

\title{
Awareness of the 4th industrial revolution among young people
}

by Nguyễn Đức Lộc, Nguyễn Thị Tuyết Thanh (Social Life Research Institute)

Article Info: $\quad$ Received 25 July 2020, Accepted 20 Aug 2020, Available online 15 Dec,2020

Corresponding author: locnd@sociallife.vn (Nguyễn Đúc Lộc Assoc.Prof., Ph.D)

https://doi.org/10.37550/tdmu.EJS/2020.04.088

\begin{abstract}
In order to have an overview of the current quality of youth labor and its readiness for the emergence of the fourth industrial revolution (or Industry 4.0), measuring the understanding of students about the Industry 4.0 in the context of Vietnam's digital economy is essential. As the young's perception in the presentday context can be seen as a crucial manifestation to evaluate their awareness levels on how this revolution impacts their joining the labor market. In addition, the young's awareness is an important information source in orienting their own behavior accordingly, which is also an indication of the level of their willingness to adapt to the digital age. As the result of previous qualitative and quantitative surveys, this article addresses the awareness characteristics of young people, thereby exploring their capacity for self-assessment about risks or career opportunities in the context of Industry 4.0.
\end{abstract}

Keywords: awareness, professional capacity, fourth industrial revolution

\section{Introduction}

Many studies have mentioned that Industry 4.0 expectedly affects many fields in contemporary society, especially in the field of labor and employment. Schwab (2018) focuses on this revolution's impact on business, economy, individuals, society, country, 
etc. The study provides an overview of the Industry 4.0. Besides, in terms of policy, it can be seen that the developed countries have made strategic preparations. Typically in the US, the National Science and Technology Council has issued a national strategy for advanced manufacturing in 2013 (Foresight, 2013). In France, a new industrial development strategy was issued by the government's technology council in 2013 (Liao, 2018). In 2014, Korean government announced "3.0 Manufacturing Innovation", which emphasizes new strategies and missions for domestic production (Kang et al., 2016). Meanwhile, Chinese Government has adopted the "Made in China 2025" strategy along with the "Internet Plus" plan in 2015. This can be considered as China's priority to accelerate data sharing and industrialization. (Li, 2015). Through these researches, we can partly imagine how developed countries have been preparing for the upcoming 4.0 industrial revolution.

More specifically, (Schröder, 2016) mentioned the importance of this industrial revolution in the business sector. Accordingly, the topic refers to significant changes in job sectors by the scientific and technological revolution. In his conclusion, the author also emphasizes that this change, however, does not lead to unemployment. Christian's view was also concurred by many researchers in the seminar on the topic of the 4th Industrial Revolution and manufacturing in Vietnam (2017). During the conference, most of the presentations did not only focus on the opportunities and challenges of Industry 4.0, but also emphasized Asia's experience in improving and transforming the quality of human resources (Udal Singh Mehta, 2017; Pavida Pananond, 2017). Hendri Saparini (2017) shared Indonesia's experience with the article "Challenges for Indonesia in the digital economic era: The appeal of skilled labor" . Meanwhile, Park Myung-Joon (2017), the author of the essay "Korean 4th Industrial Development Fund", conducted a survey on 25 million workers in 414 enterprises and agencies. He mentioned impressive figures on the transformation in employment, which shows that about 49.7 percent of global workforce's working time can now be "automated" in 2030. According to Park Myung-Joon (2017), emerging jobs are related to software engineering, data science, and their respective specialists.

In that context, the adaptability in a transforming industry towards the digital economy is creating challenges for young people, they are hence required to be fully aware of social change and thereby adapt to this fast-paced environment.

\section{Research Methods}

In this article, we collect and analyze information by both quantitative and qualitative methods. 
Nguyễn Đức Lộc, Nguyễn Thị Tuyết Thanh - Volume 2 - Issue 4-2020, p.442-457.

- With quantitative research method, a questionnaire-survey is used with the following sampling method

The data sampling method of this article follows the typical quotas and stratification. According to Hair and CTG (2006), the minimum sample size used for factor analysis is 50 , preferably 100 . While the ratio of observations / measurement variables is 5: 1 (each measurement variable needs minimum 5 times of observations). If using Exploratory Factor Analysis, the minimum sample size must be five times higher than the total number of observed variables. The minimum sample size for university students, therefore, will be: $\mathrm{n}=5 * \mathrm{~m}=5 * 20=100$. Whilst that of the employee will be: $\mathrm{n}=5 *$ $\mathrm{m}=5 * 30=150$. Accordingly, 1000 quantitative questionnaires, based on quota and multi-stage sampling, are conducted and divided into two groups: final-year students by sectors and the working people in four key industries of the city.

- With qualitative research method, we conducted in-depth interviews two main subject groups, namely students and working people:

A total of 110 in-depth interviews are conducted. Among those, about $10 \%$ of the subjects, which is equivalent to 97 interviews, is also interviewed according to the semistructured technique. In addition, unstructured interviews are conducted on 8 business managers and 5 lecturers based on living context, practical work in order to research experiences, labor trends during the Industry 4.0 era.

\section{Findings}

\subsection{Understanding about labor market trends in the context of Industry 4.0}

The survey results show that students of both genders have certain interest in Industry 4.0. In particular, their means of information access are mainly through the media. A senior student at the department of Chemical Technology of a public university explained the concept of Industry 4.0 that:

"I have heard about this term a lot from the Internet, from relatives and from my internship. This is the era when machines have gradually replaced humans. Machines can be linked together by interconnected software under the control of humans." (SV01, Year 4, Chemical Technology, A public university)

Another student also studying Chemical Technology at the same university added:

"A lot, from the media and also from my friends who regularly share about Industry 4.0. Industry 4.0 will change the world, it will connect everything together through the internet. At that time, automation will take over human's role in many job sectors. This revolution has already happened throughout the world, 
but it has not made much progress in Vietnam." (SV01, Year 4, Chemical Technology, A public university)

The commonly used words among the young such as: "The 4th Industrial Revolution", "machine", "link", "software", "connection", "automation", etc." have described the basic features of the Industry 4.0 concept in the digital economy. However, these understandings mostly stay at word-of-mouth level. From the above data, an assumption is made that whether the digital media (search results on August 27th / 2018 on Google for about $6,350,000$ in 0.42 seconds) had particularly impacted on young people's perception about Industry 4.0. However, it is worth mentioning that, to what extent is this understanding?

Perhaps the media and people's interest stem from the view and policies of the government in this matter.

Thus it can be seen that, in the current context, media and social networks are gradually becoming one of the main channels to access information among students. To a certain extent, the media are having effects on students' understanding. However, there are still many existing issues in communication about this subject, which was mentioned as an example in the following sharing of a female manager, former head of the Faculty of International Relations at a public university:

"4.0 now in Vietnam is mainly propaganda while it is only 2.0. Because of that intimidation and propaganda, people keep thinking 4.0 as something sublime, and many people find it unattainable."(Female manager 01, former head of the Faculty of International Relations, Public Sector University)

When the concept of Industry 4.0 is brought to the media, more or less, it creates different perceptions among people. Especially the universities see this as a historical turning point of the humankind, and the Vietnamese national leaders consider this as an opportunity to create an image of a developed country. However, the media wave also raised many doubts about the real impact of this revolution on Vietnam's life and development. Therefore, we also acknowledge the opinion of an educational expert that the goal of education is quite extensive and covers all areas of society. Industry 4.0 or similar names is one of the critical conditions for socio-economic development, but it is only a part of the contents of education and training. Thus, if we only focus on Industry 4.0 and start-up, it is not adequate and easy to turn into a movement that is purely formal and non-essential:

"Although I worked as a manager of human resources development department for a US state for many years, I have never heard of high-quality human resources, but this term is popular in Vietnam. The same goes to when we talk a lot about Technology 
4.0 or entrepreneurship and want to include it in high school and university curriculum. In the age of technology and integration, everything will self-change in a fast pace, thus in basic education the strategy should not be built by phase or campaign, but must be inclusive and permanent" (Male expert 01, member of National Council for Education and Human Development)

The assessment of this expert, perhaps also implies the bias in the meaning and concept of Industry 4.0, as well as implicit consequences for educational perspectives in Vietnam, which currently have conflicts between social expectations and the education reforms of the Ministry of Education and Training.

The analysis result presented in Figure 1 below shows the general situation of the level of understanding of young human resources, almost all of the concepts related to Industry 4.0 are not understood fully and applied practically by the majority of young people. In particular, at the level of clear understanding and practical application, only the term "Communication and network connection" has the highest rate of choice with $25.1 \%$ while the rest are assessed by young people for their level of understanding and appliance below 10\%; the level of awareness without practical use ranges from 10-20\% with all terms except the term "Robot" with $25.4 \%$. Especially, in most terms, except for the term "Communication and Internet connection" (16.1\%), the proportion of young human resources to have never heard or heard about but do not understand accounting for a high proportion (ranging from $23.3 \%$ to 67\%), of which the term "Virtual industrialization" has never been heard by young people or heard about but not understood, accounting for the highest percentage with $67 \%$.

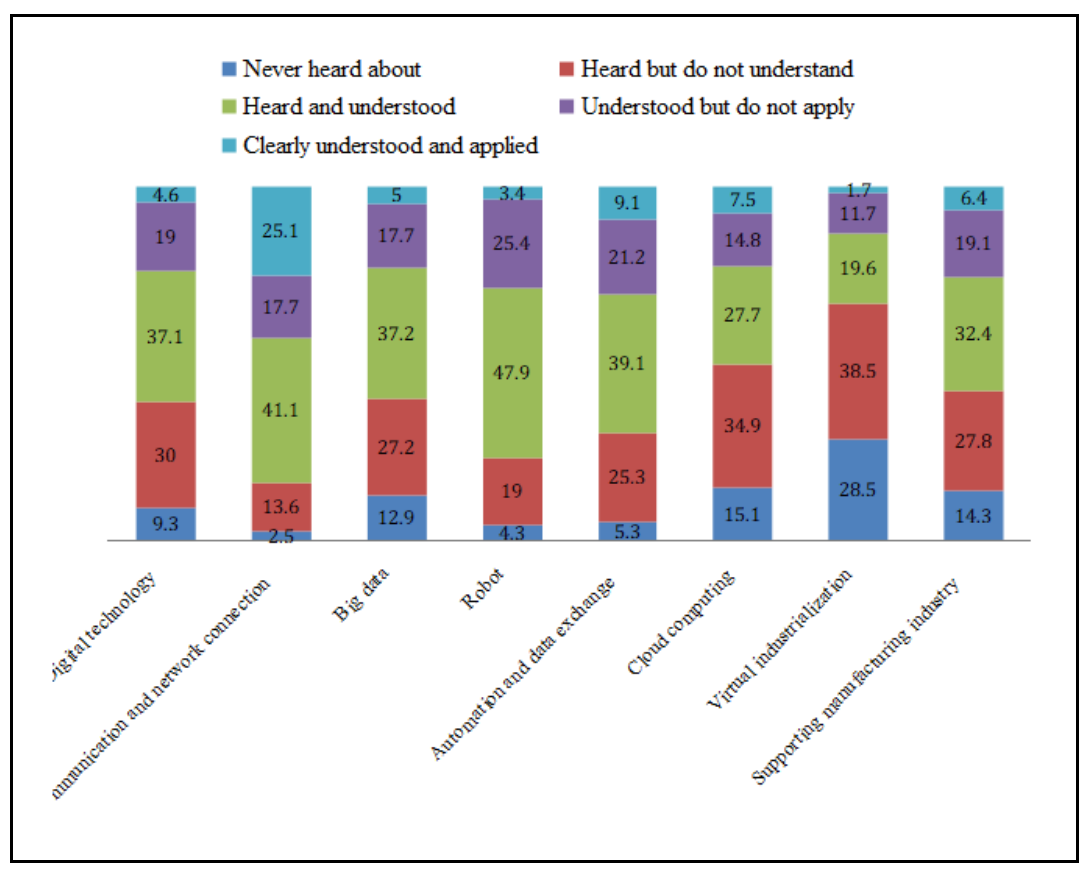


Figure 1. Young people's level of understanding about related terms of Industry 4.0

To analyze the differences in the perception of labor market trends between students (university students) and working people (working people in enterprises), we conduct a sample average test (T-Test) and the results in Table 1 show sufficient statistical evidence $(\mathrm{p}<0.01)$ to indicate a difference in the level of understanding of the term "Digital Technology" (2.72 vs. 2.91) between these two groups. The results were similar to the assessment of understanding of the terms "Big data" (2.67 vs. 2.87), "Robot" (2.97 vs 3.16), and "Virtual Industrialization"(2.11 vs. 2.32). On the other hand, when comparing the level of understanding between working people and students with terms such as "Communication and network connection", "Automation and data exchange", "Cloud computing" and "Supporting manufacturing industry", the results of the test for mean difference between these two groups did not have enough statistical evidence to indicate the difference.

TABLE 1. Comparison of the difference in understanding of terms related to Industry 4.0 between students and working people

\begin{tabular}{lccccccc}
\hline & \multicolumn{9}{c}{ Subjects } & & \\
\cline { 2 - 5 } Understanding of terms Industry 4.0 & Working people & \multicolumn{2}{c}{ Students } & & p-value \\
\cline { 2 - 6 } & Mean & S.D & Mean & S.D & & \\
\hline Digital Technology & 2,72 & 1,019 & 2,91 & 0,968 & & 3,852 & $0,004^{*}$ \\
Communication and network connection & 3,52 & 1,110 & 3,46 & 1,045 & & 4,782 & 0,432 \\
Big data & 2,67 & 1,039 & 2,87 & 1,056 & 0,508 & $0,004^{*}$ \\
Robot & 2,97 & 0,889 & 3,16 & 0,819 & 0,000 & $0,001^{*}$ \\
Automation and data exchange & 3,04 & 1,018 & 3,04 & 1,025 & 0,178 & 1,000 \\
Cloud computing & 2,67 & 1,139 & 2,62 & 1,118 & 0,002 & 0,465 \\
Virtual Industrialization & 2,11 & 0,963 & 2,32 & 1,117 & 33,633 & $0,002^{*}$ \\
Supporting manufacturing industry & 2,72 & 1,132 & 2,80 & 1,082 & 0,362 & 0,271 \\
\hline
\end{tabular}

* Statistical significance in $\alpha=0,01$; Source: Results from the 2019 survey

The difference in the level of understanding of the terms "Digital technology", "Big data", "Robot" and "Virtual industrialization" between the the working people and students is presented through Table 2 below. The results show that working people who have never heard or heard but did not understand the four terms above account for a much higher proportion than that of students. At the same time, students who have heard and understood the four terms above accounts for a much higher percentage than those who have already worked. At this point, the university training environment is likely playing its role well in raising awareness for students (one of young human resources) to understand the above four 
terms in the Industry 4.0 era. The level of clear understanding and practical application accounts for the most modest percentage in these two subjects, similar to the aforementioned comments, although there is a little difference. The similarity in level of understanding in terms of Industry 4.0 such as "Communication and network connection", "Automation and data exchange", "Cloud Computing", and "Manufacturing Industry Support "between 02 subjects of working people and students is demonstrated in Table 2 below with the results: both working people and students understand well and apply in practice the term "Communication and network connection" with the highest rate of all the investigated terms related to Industry 4.0 (28.3\% and 20.3\%), almost all of them have heard or heard and understood this term with a very high rate (97.5\% on both objects). Similar to the term "Automation and data exchange", almost all of them have heard or heard and understood this term with a very high rate $(95.2 \%$ for working people and $94 \%$ with students). Particularly for the two terms "Cloud Computing" and "Supporting Manufacturing Industry", it seems that both students and working people are quite unfamiliar with this term when they rated "never heard" from 13-16.8\%, however, similar to the two terms mentioned above, the number who have heard or heard and understood these terms reached a fair high rate $(86 \%$ with working people and $83.2 \%$ with school attendees in the term "Cloud computing", $84.8 \%$ with working people and $87 \%$ with students in the term "Supporting manufacturing industry").

TABLE 2: The similarity in the level of understanding of terms related to the $4^{\text {th }}$ Industrial Revolution between students and working people

\begin{tabular}{|c|c|c|c|c|c|}
\hline & & \multicolumn{4}{|c|}{ Objects } \\
\hline & & \multicolumn{2}{|c|}{ Working people } & \multicolumn{2}{|c|}{ Students } \\
\hline & & Quantity & Scale & Quantity & Scale \\
\hline \multirow{5}{*}{$\begin{array}{l}\text { Communication } \\
\text { and Network } \\
\text { connection }\end{array}$} & Never heard about & 15 & $2,5 \%$ & 10 & $2,5 \%$ \\
\hline & Heard but did not understand & 79 & $13,2 \%$ & 57 & $14,2 \%$ \\
\hline & Heard and understood & 258 & $43,0 \%$ & 153 & $38,3 \%$ \\
\hline & Understood but did not apply & 78 & $13,0 \%$ & 99 & $24,8 \%$ \\
\hline & Understood and applied & 170 & $28,3 \%$ & 81 & $20,3 \%$ \\
\hline \multirow{5}{*}{$\begin{array}{l}\text { Automation and } \\
\text { data exchange }\end{array}$} & Never heard about & 29 & $4,8 \%$ & 24 & $6,0 \%$ \\
\hline & Heard but did not understand & 155 & $25,8 \%$ & 98 & $24,5 \%$ \\
\hline & Heard and understood & 240 & $40,0 \%$ & 151 & $37,8 \%$ \\
\hline & Understood but did not apply & 118 & $19,7 \%$ & 94 & $23,5 \%$ \\
\hline & Understood and applied & 58 & $9,7 \%$ & 33 & $8,3 \%$ \\
\hline
\end{tabular}




\begin{tabular}{llrrrr} 
Cloud computing & Never heard about & 84 & $14,0 \%$ & 67 & $16,8 \%$ \\
& Heard but did not understand & 216 & $36,0 \%$ & 133 & $33,3 \%$ \\
& Heard and understood & 168 & $28,0 \%$ & 109 & $27,3 \%$ \\
& Understood but did not apply & 79 & $13,2 \%$ & 69 & $17,3 \%$ \\
& Understood and applied & 53 & $8,8 \%$ & 22 & $5,5 \%$ \\
\multirow{2}{*}{$\begin{array}{l}\text { Supporting } \\
\text { manufacturing }\end{array}$} & Never heard about & 91 & $15,2 \%$ & 52 & $13,0 \%$ \\
& Heard but did not understand & 169 & $28,2 \%$ & 109 & $27,3 \%$ \\
& Heard and understood & 203 & $33,8 \%$ & 121 & $30,3 \%$ \\
& Understood but did not apply & 89 & $14,8 \%$ & 102 & $25,5 \%$ \\
& Understood and applied & 48 & $8,0 \%$ & 16 & $4,0 \%$
\end{tabular}

With young men and women, we also conduct a sample average test (T-Test) to analyze whether there is a difference in perception of labor market trends between men and women. And the results in Table 3 show that we have enough statistical evidence at $\mathrm{p}<0.01$ to point out that there is a difference between men and women in the level of understanding of the term "Digital Technology" (2 , 92 versus 2.73); "Big data" (2.91 vs. 2.66); "Cloud Computing" (2.87 vs. 2.52); "Virtual Industrialization " (2.44 vs. 2.06) and "Supporting manufacturing industry" (2.91 vs. 2.67). The results were similar to the assessment of the level of understanding of the terms "Communication and network connection" (3.38 versus 3.56) between men and women, but at the statistical significance level $\mathrm{p}<0.05$. On the other hand, when comparing the level of knowledge between men and women with terms such as "Robot", "Automation and data exchange", the results of the mean difference test between these two groups does not have enough statistical evidence to indicate any difference.

Differences in the level of understanding of the terms "Digital technology", "Communication and Network connection", "Big data", "Cloud computing" and "Virtual Industrialization" and "Supporting manufacturing industry" between these two objects men and women are more specific through the Table 3 below. The results show that in terms "Digital Technology", "Big data", "Cloud computing" and "Virtual industrialization" and "Supporting manufacturing industry", young men who have never heard or heard but did not understand about the five aforementioned terms account for a much lower percentage than young female workers, at the same time, it is also young men who heard and understood those five terms account for a much higher rate than their female fellows. However, as for the term "Communication and Network connection", young female who understood and applied this term in practice account for a much higher proportion than the male counterpart. At the same time, the proportion of women who have never heard of it, or heard but did not understand also accounts for a lower rate than 
the male one. Up to this point, the term "Communication and Network connection" in the era of Industry 4.0 seems to be more attractive to young women, and men seem to have a more comprehensive attitudes in issues related to Industry 4.0 than women.

TABLE 3: Comparison of differences in understanding of terms related to the $4^{\text {th }}$ Industrial Revolution between men and women

\begin{tabular}{|c|c|c|c|c|c|c|}
\hline \multirow{3}{*}{$\begin{array}{l}\text { Understanding the term of the } 4^{\text {th }} \\
\text { Industrial Revolution }\end{array}$} & \multicolumn{4}{|c|}{ Subjects } & \multirow{3}{*}{$\mathbf{F}$} & \multirow{3}{*}{ p-value } \\
\hline & \multicolumn{2}{|c|}{ Male } & \multicolumn{2}{|c|}{ Female } & & \\
\hline & Mean & S.D & Mean & S.D & & \\
\hline Digital technology & 2,92 & 1,006 & 2,73 & 0,995 & 0.950 & $0,003^{*}$ \\
\hline Communication and Network connection & 3,38 & 1,060 & 3,56 & 1,093 & 3,881 & $0,010 * *$ \\
\hline Big data & 2,91 & 1,039 & 2,66 & 1,046 & 4,462 & $0,000 *$ \\
\hline Robot & 3,10 & 0,881 & 3,02 & 0,857 & 2,203 & 0,162 \\
\hline Automation and data exchange & 3,11 & 0,977 & 2,99 & 1,042 & 0,276 & 0,077 \\
\hline Cloud computing & 2,87 & 1,103 & 2,52 & 1,128 & 2,741 & $0,000^{*}$ \\
\hline Virtual industrialization & 2,44 & 1,092 & 2,06 & 0,970 & 23,279 & $0,000 *$ \\
\hline Supporting manufacturing industry & 2,91 & 1,108 & 2,67 & 1,106 & 2,164 & $0,001 *$ \\
\hline
\end{tabular}

* Statistically significant at $\alpha=0,01$; Source: Survey results 2019

The similarity in the level of understanding of terms related to Industry 4.0 such as "Robot", "Automation and data exchange" between young male and female human resources is shown in Table 4 below: both young men and women understood clearly and have applied the term "robot" into practice with a very low rate $(4.4 \%$ and $2.8 \%)$, people who have heard or heard and understood this term account for a very high rate $(91.7 \%$ for men and $92.7 \%$ for women); With the term "Automation and data exchange", it is different from the term "Robot" when both men and women have a higher rate of understanding and have applied this term in practice. (9.1\%), almost all of them have heard or heard and understood this term with a relatively high rate $(87.5 \%$ for men and $84.5 \%$ for women). The rate of never heard about these two terms of both subjects accounts for a low rate from $3.3 \%-6.4 \%$. However, for the answer of never heard and heard but did not understand, the rate is remarkable at the level of $22.2 \%-32.7 \%$.

$T A B L E 4$. The similarity in the level of understanding of terms related to Industry 4.0 between young male and female human resources 


\begin{tabular}{|c|c|c|c|c|c|}
\hline & & \multicolumn{4}{|c|}{ Objects } \\
\hline & & \multicolumn{2}{|c|}{ Male } & \multicolumn{2}{|c|}{ Female } \\
\hline & & Quantity & Scale & Quantity & Scale \\
\hline \multirow[t]{5}{*}{ Robot } & Never heard about & 14 & $3,9 \%$ & 29 & $4,5 \%$ \\
\hline & Heard but did not understand & 66 & $18,3 \%$ & 124 & $19,4 \%$ \\
\hline & Heard and understood & 168 & $46,5 \%$ & 311 & $48,7 \%$ \\
\hline & Understood but did not apply & 97 & $26,9 \%$ & 157 & $24,6 \%$ \\
\hline & Understood and applied & 16 & $4,4 \%$ & 18 & $2,8 \%$ \\
\hline \multirow{5}{*}{$\begin{array}{l}\text { Automation } \\
\text { and data } \\
\text { exchange }\end{array}$} & Never heard about & 12 & $3,3 \%$ & 41 & $6,4 \%$ \\
\hline & Heard but did not understand & 85 & $23,5 \%$ & 168 & $26,3 \%$ \\
\hline & Heard and understood & 148 & $41,0 \%$ & 243 & $38,0 \%$ \\
\hline & Understood but did not apply & 83 & $23,0 \%$ & 129 & $20,2 \%$ \\
\hline & Understood and applied & 33 & $9,1 \%$ & 58 & $9,1 \%$ \\
\hline
\end{tabular}

Source: Survey results 2019

The in-depth interview data also describes the understanding of students and young workers about the concepts in the $4^{\text {th }}$ Industrial Revolution:

"Actually, I've been heard about this for a long time, I just heard but haven't learned much about this. I imagine it as a modern technology which can help me save time, save effort, bring high efficiency. But honestly I just imagine and I don't really know what it is. " (Male, 29 years old, English teacher)

"About Industry 4.0, I have heard a lot about it, but to understand in details, I don't know much about it. I only understand the $4^{\text {th }}$ Industrial Revolution as a digital technology, which is more modernized in production and automobile technology. (Female, 24 years old, an employee of a foreign enterprise)

The words used by insiders such as: the fourth revolution, machines, links, software, connections, automation ... have described the basic features of the Industry 4.0 concept in the digital economy. It can be seen that the above cases describe the basic concepts of the Industry 4.0 in the digital economy. However, these understandings mostly stay at the level of word-of-mouth, conversations or videos about Industry 4.0 in the digital economy.

3.2. Young people's opinion about the effects of The Fourth Industrial Revolution on the labour market. 
Understanding definitions related to The Fourth Industrial Revolution, young people have been aware of the trend of the labor market. This requires a preparation to meet demands of the future labour market.

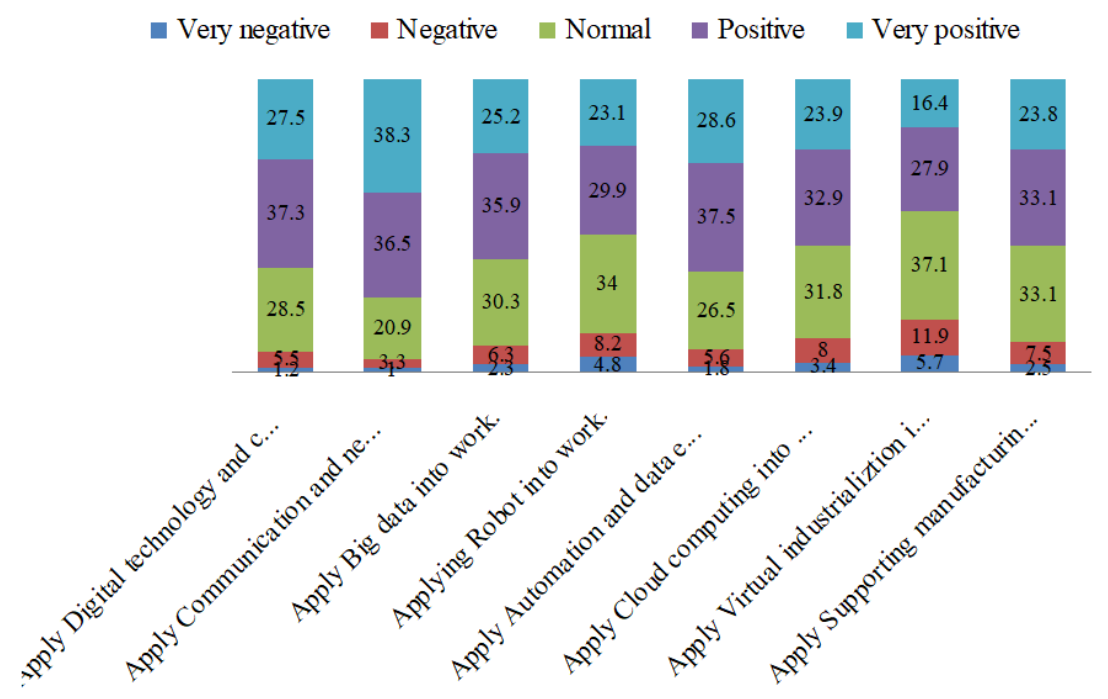

Figure 2: Young people's opinion about the effects of The Fourth Industrial Revolution on the labour market.

Figure 2 shows young people's opinion about the effects of The Fourth Industrial Revolution on the labour market: The top 3 factors considered to bring highest positive effects are Apply communication and network connection into work (74.8\%, very positive $38.3 \%$ ), Apply Automation and data exchange into work (66.1\%, very positive $28.6 \%$ ), Apply Digital technology and creativity into work (64.8\%, very positive $27.5 \%$ ).

Nowadays, labour market tends to focus on information technology, electronic technology, car technology or software development. Markets require young labour resources to have good health and good knowledge of their major. Energy and eagerness are the advantages of young labour. Somehow they can gain experience of 2 or 3 working years just in 1 years. They also study and research to apply gained knowledge and skills into work. (Female, 30 years old, Accountant).

On the other hand, "Apply Virtual industrialization into work" is at the lowest rate (very positive $16.4 \%$, very negative $17.6 \%$ ). It is understandable because most people joining in this survey have never heard or known much about the definition of "Virtual industrialization". That is the reason why the job tendency related to this definition is lowest.

To indicate whether there is a difference in perception of the impact of Industry 4.0 on labor market between working people and students, we conducted $\mathrm{T}$ - Test to analyse the 
difference in opinion of students and working people about the tendency of labour market. The result in Table 5 shows enough statistical evidence at $p<0.01$ which points out there is a difference between two respondent groups in considering the trend: Apply digital technology and creativity into work (3.78 compared to 3.94); Apply Big data into work (3.67 compared to 3.88); Apply robots into work (3.43 compared to 3.81); Apply cloud computing into work (3.59 compared to 3.77); Apply Virtual Reality technology into work (3.23 compared to 3.60) and Apply Supporting manufacturing industry into work (3.60 compared to 3.81). On the other hand, there is no statistical evidence from the test to conclude the difference between two groups when it comes to Apply communications and Network connectioninto work and Apply automation and data exchange into work.

TABLE 5: Comparison of levels of consideration about the tendencies of The Fourth Industrial Revolution on the labor market between working people and students

\begin{tabular}{|c|c|c|c|c|c|c|}
\hline \multirow{3}{*}{ Tendecy of Industry 4.0} & \multicolumn{4}{|c|}{ Objects } & \multirow{3}{*}{$\mathbf{F}$} & \multirow{3}{*}{ p-value } \\
\hline & \multicolumn{2}{|c|}{ Working people } & \multicolumn{2}{|c|}{ Students } & & \\
\hline & Mean & S.D & Mean & S.D & & \\
\hline $\begin{array}{l}\text { Apply Digital technology and creativity } \\
\text { into work. }\end{array}$ & 3,78 & 0,989 & 3,94 & 0,825 & 51,359 & $0,005^{*}$ \\
\hline $\begin{array}{l}\text { Apply Communication and network } \\
\text { connection into work. }\end{array}$ & 4,06 & 0,940 & 4,10 & 0,835 & 16,420 & 0,518 \\
\hline Apply Big data into work. & 3,67 & 1,034 & 3,88 & 0,870 & 30,983 & $0,001^{*}$ \\
\hline Applying Robot into work. & 3,43 & 1,136 & 3,81 & 0,937 & 27,370 & $0,000^{*}$ \\
\hline $\begin{array}{l}\text { Apply Automation and data exchange } \\
\text { into work. }\end{array}$ & 3,81 & 1,025 & 3,93 & 0,843 & 33,280 & 0,050 \\
\hline Apply Cloud computing into work. & 3,59 & 1,103 & 3,77 & 0,909 & 34,257 & $0,006^{*}$ \\
\hline Apply Virtual industrializtion into work. & 3,23 & 1,126 & 3,60 & 0,937 & 7,158 & $0,000^{*}$ \\
\hline $\begin{array}{l}\text { Apply Supporting manufacturing } \\
\text { industry into work }\end{array}$ & 3,60 & 1,041 & 3,81 & 0,913 & 23,659 & $0,001 *$ \\
\hline
\end{tabular}

* Statistical significant at $\alpha=0,01$; Source: Results from 2019 survey

Table 5 shows more details about the difference in opinion of students and working people about the tendency of the Fourth Industrial Revolution in "Apply digital technology and creativity into work; Apply Big data into work; Apply robots into work; Apply cloud computing into work; Apply Virtual industrialization into work; Apply Supporting manufacturing industry into work. The result shows that students' opinions are more optimistic in 6 tendencies, especially Apply Virtual Reality technology into work $(56.0 \%>$ $36.5 \%)$, Apply robots into work $(64.5 \%>45.3 \%)$, Apply Supporting manufacturing 
industry into work $(66.3 \%>50.7 \%)$ and Apply digital technology and creativity into work $(73.8 \%>58.8 \%)$. Meanwhile, working people tend to be more pessimistic, especially in Apply Virtual industrialization into work $(22.2 \%>10.8 \%)$, Apply robots to work $(17.3 \%>$ $6.5 \%$ ). In general, students tend to think more optimistically since they have not been involved in difficulties of working life as their counterpart. However, we still need to explain why working people do not appreciate the application of robot into work while robot is of one the key trends of the Fourth Industrial Revolution.

The Industry 4.0 can improve the income and living standard of everyone, as well as promote the global economy. It also brings many opportunities and challenges when automation gradually replaces the role of human in the production chain. The labour market will be more challenging and young labors are required to have better knowledge and skills rising demands from employers.

To explore the awareness of young people about Industry 4.0 in terms of knowledge as well as opportunities and challenges to their career, this survey asks people 7 questions to measure considerations among young people about their own opportunities and challenges from the labour market in the Industry 4.0. The questions (indicators) include: opportunities and threats in job searching and options, job changing, technology control, working in globalization, income stability, ability to work individually and teamwork. We use scale 1 to 5 ( 1 is the lowest and 5 is the highest).

\section{Conclusion}

The data of this survey shows that most young people "just get to know, but do not really understand" the definitions related to the Fourth Industrial Revolution. Even a majority have never heard about these terms while they are still limited in daily use. This is understandable because the definition of 4.0 Industrial Revolution was not released until its Industry 4.0st appearance in the Hannover Fair (Germany) in 2011. Moreover, in Vietnam, the concept of Industry 4.0 in the digital economy has only been used in the mass media since the Report on Career Future from World Economic Forum (WEF) in 2016. This report was translated and summarized by a number of mainstream newspapers. Therefore, the limited knowledge about Industry 4.0 among young people is explainable. On the other hand, from the above data, an assumption is made that whether the concept of the Industry 4.0 in the Vietnamese digital economy concerned and reported by the digital media on a daily basis (daily search results of 11/11/2019 on Google produced about 1,750,000 in 0.42 seconds) has affected people's awareness, especially young people to some extents. However, another concern to be mentioned here is how deep is the level of this knowledge? 
The main data of this article belongs to the research topic "Awareness and Capacity assessment of high-quality young human resources \& Proposed solutions to meet the recruitment demands of enterprises in the context of Industry 4.0 in Ho Chi Minh city" of The Ho Chi Minh City

\section{References}

Đỗ Quỳnh Chi. (2017). Liên kết thiếu trong chuỗi? Các chế độ thương mại và tiêu chuẩn lao động trong chuỗi cung ứng hàng may mặc, giày dép và điện tử ở Việt Nam. Việc làm bền vũng trong chuỗi cung ứng toàn cầu - Vai trò của các chính sách công nghiệp, phương thức mua sắm và chinh sách thuoong maii. Hồ Chí Minh: Trung tâm Nghiên cứu quốc tế (SCIS).

Drath, R., \& Horch, A. (2014). Industrie 4.0: Hit or hype?[industry forum]. IEEE industrial electronics magazine, 56 - 58.

Gorle, P., \& Clive, A. (2013). Positive Impact of. International Federation of Robotics.

Richard E., W. (2009). What is shared? A framework for understanding shared innovation within communities. Educational Technology Research and Development, 315-332.

Romero, F., \& Pereira, A. (2017). A review of the meanings and the implications of the Industry 4.0 concept. Procedia Manufacturing, 1206-1214.

Salkin, C., Oner, M., Ustundag, A., \& Cevikcan, E. (2018). A Conceptual Framework for Industry 4.0. New York: Springer.

Schwab, K. (2018). The Global Competitiveness Index 2017-2018 edition. Word Economic forum.

Wan, J., Yi, M., Li, D., Zhang, C., Wang, S., \& Zhou, K. (2016). Mobile Services for Customization Manufacturing Systems: An Example of Industry 4.0. IEEE Access, 8977-8986.

Bates, A., \& Sangra, A. (2011). Managing technology higher education: Strategies for Transforming Teaching and Learning. New York: Jossey-Bass.

Bindé, J. (2005). Towards knowledge societies. Paris: UNESCO Publishing.

Bùi Thị Ngọc Lan. (2017, 8 22). lyluanchinhtri.vn. Được truy lục từ Cách mạng công nghiệp lần thứ tư và một số vấn đề đặt ra với Việt Nam: http://lyluanchinhtri.vn/home/index.php/bai-noibat/item/2134-cach-mang-cong-nghiep-lan-thu-tu-va-mot-so-van-de-dat-ra-voi-viet-nam.html

BNeeta, B. (2016). Lifelong Learning in Knowledge Society. Trong P. Pablos , \& R. Tennyson, Impact of Economic Crisis on Education and the Next-Generation Workforce (trang 263 284). Hershey: IGI Global.

Nguyên Long. (2017, 4 16). vov.vn. Được truy lục từ Cuộc cách mạng 4.0 và những tác động tới Việt Nam: https://vov.vn/kinh-te/cuoc-cach-mang-40-va-nhung-tac-dong-toi-viet-nam-614138.vov

Pananond, P. (2017). Economic Upgrading in Global Value Chains: Moving toward Thailand 4.0? Industry 4.0 and Vietnam Manufacturing. Ho Chi Minh: FES and SCIS.

Park, M.-j. (2017). Development Trajectories of Industry 4.0 in South Korea. Industry 4.0 and Vietnam Manufacturing. Ho Chi Minh : FES and SCIS.

Park, S. (2016). Development of Innovative Strategies for the Korean Manufacturing Industry by Use of the Connected Smart Factory (CSF). Procedia Computer Science, 744 - 750.

Pfeiffer, S., \& Suphan., A. (2015). The Labouring Capacity Index: Living Labouring Capacity and Experience as Resources on the Road to Industry 4.0. Stuttgart: University of Hohenheim - Chair for Sociology.

Porfelid, E., \& Savickas, M. (2011). Revision of the career maturity inventory: The adaptability form. ournal of Career Assessment, 355-374. 
Nguyễn Đức Lộc, Nguyễn Thị Tuyết Thanh - Volume 2 - Issue 4-2020, p.442-457.

pwc. (2016). Industry 4.0: Building the digital enterprise. India: Pwc.

Roblek, V., Meško, M., \& Krapež, A. (2016). A Complex View of Industry. Sage Open. doi:10.1177/2158244016653987

Saparini, H. (2017). Challenges for Indonesia in digital economic era: The absorption of highskilled labor. Industry 4.0 and Vietnam Manufacturing. Ho Chi Minh: FES and SCIS.

Savickas, M. (2013). The 2012 Leona Tyler award address: Constructing careers-Actors, agents, and authors. The Counseling Psychologist, trang 648-662.

Saviskas, M. (2005). The theory and practice of career construction. Career development and counseling: Putting theory and research to work, trang 42-70.

Schmidt, R., Möhring, M., Härting, R.-C., Reichstein, C., Neumaier, P., \& Jozinović, P. (2015). Industry 4.0 - Potentials for Creating Smart Products: Empirical Research Results. International Conference on Business Information Systems, 16-27.

Schröder, C. (2016). The challenges of industry 4.0 for small and medium-sized enterprises. Born: Friedrich-Ebert-Stiftung.

Schuh, G., Anderl, R., Gausemeier, J., Hompel, M., \& Wahlster, W. (2017). Industrie 4.0 Maturity Index. Managing the Digital Transformation of Companies. Munich: National Academy of Science and Engineering.

Schumacher, A., Erol, S., \& Sihn, W. (2016). Industrie 4.0 Maturity Index. Managing the Digital Transformation of Companies. Procedia CIRP, 161-166.

Skilton, M., \& Hovsepian, F. (2018). The 4th Industrial Revolution Impact. Trong M. Skilton, \& F. Hovsepian, The 4th Industrial Revolution: Responding to the Impact of Artificial Intelligence on Business (trang 3-28). New York: Palgrave Macmillan.

Staufen, A. (2015). China - Industry 4.0 Index 2015. Shanghai: Staufen A. G.

Stock, T., \& Seliger, G. (2016). Opportunities of sustainable manufacturing in industry 4.0. Procedia Cirp, 536 - 541.

Sulistiani, W., \& Handoyo, S. (2018). Career Adaptability: The Influence of Readiness and Adaptation Success in the Education Context: a Literature Review. Social Science, Education and Humanities Research, 133, 195-205.

Symaco, L. (2013). Education and knowledge society in the Asia-Pacific. Asia Pacific Journal of Education, 133-139.

Symaco, L. P. (2012). Higher Education in the Philippines and Malaysia: The learning region in the age of knowledge-based societies. Journal of International and Comparative Education (JICE), 40-51.

Terence, M. (1994). Politics, Markets and Schools: The Central Issues. Trong M. Terence, \& D. Bridges, Education and the Market Place (trang 153 - 168). London: Falmer Press.

Tian, Y., \& Fan, X. (2014). Adversity quotients, environmental variables and career adaptability in student nurses. Journal of Vocational Behavior, 251-257.

Truong, M. V., \& Nguyen, V. A. (2017). The Fourth Industrial Revolution: A Vietnamese Discourse. Ha Noi: Friedrich Ebert Stiftung Vietnam.

Veza, I., Mladineo, M., \& Peko, I. (2015). Analysis of the current state of Croatian manufacturing industry with regard to industry 4.0. Croatian Association of Production Engineering, 3-6.

Vũ Xuân Hùng. (2017, 1 1). www.nhandan.com.vn. Được truy lục từ thách thức lớn với thị trường lao động: http://www.nhandan.com.vn/cuoituan/doi-song-xa-hoi/item/31719802thach-thuc-lon-voi-thi-truong-lao-dong.html 
Vương, Đ. Q. (2016). Chuyển dịch cơ cấu kinh tế Thành phố Hồ Chí Minh tầm nhìn đến 2025. Tài chính. Đã truy lục 25 8, 2016, từ http:/tapchitaichinh.vn/nghien-cuu-trao-doi/chuyendich-co-cau-kinh-te-tp-ho-chi-minh-tam-nhin-den-nam-2025-86804.html

Wang, Z., \& Fu, Y. (2015). Social support, social comparison, and career adaptability: A moderated mediation model. Social Behavior and Personality: an international journal, 649-659.

WEF. (2018, 10 16). www.weforum.org. Được truy lục từ The Global Competitiveness Report 2018: https://www.weforum.org/reports/the-global-competitveness-report-2018

Worldbank. (2018, 10 31). Được truy lục từ Tương lai việc làm việt nam: Khai thác xu hướng lớn cho sự phát triển thịnh vượng hơn:

https://www.worldbank.org/vi/country/vietnam/publication/vietnam-future-jobsleveraging-mega-trends-for-greater-prosperity 